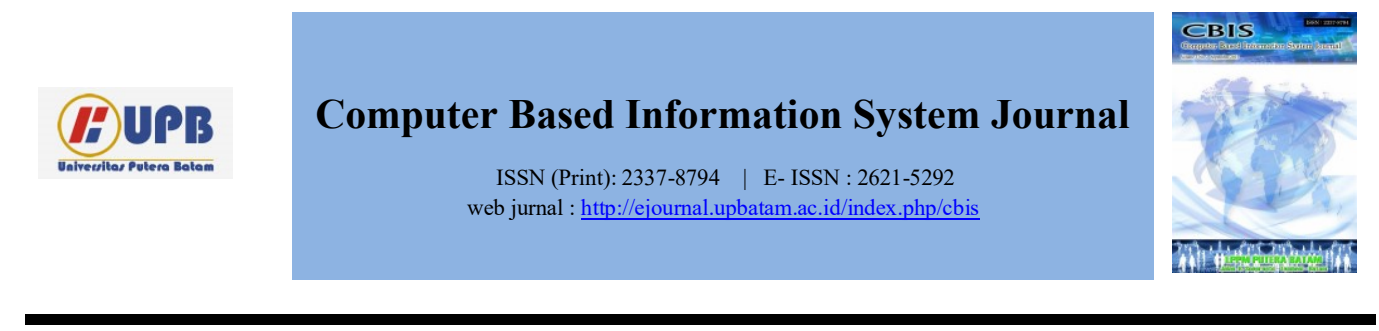

\title{
Aplikasi Pendaftaran dan Penyerahan Berkas Persyaratan Nikah KUA Kec. Koto Tangah Padang
}

\author{
Rifa Turaina ${ }^{1}$, Nency Extise Putri ${ }^{2}$, Novi Aldi Putra ${ }^{3}$ \\ ${ }^{123}$ Program Studi Sistem Informasi, STMIK Indonesia Padang \\ Jl. Khatib Sulaiman Dalam No 1 Padang, Telp (0751) 7058325
}

\section{INFORMASI ARTIKEL}

Diterima Redaksi: 6 Desember 2020

Diterbitkan Online: 24 Maret 2021

\begin{tabular}{l} 
KATA KUNCI \\
\hline Applications, marriage, online \\
KORESPONDENSI \\
\hline E-mail: \\
11rifaturaina@stmikindonesia.ac.id, \\
$\frac{2}{2}$ nencyextiseputri@stmikinodnesia.ac.id, \\
3novialdiputra@yahoo.co.id
\end{tabular}

\section{PENDAHULUAN}

KUA merupakan pusat pelayanan masyarakat dalam bidang keagamaan, maka diharapkan dapat memberikan pelayanan yang lebih mempermudah masyarakat yang akan melangsungkan pernikahan dan informasi informasi untuk mengefesienkan proses - proses yang ada didalamnya. KUA Kec. Koto Tangah http://ejournal.upbatam.ac.id/index.php/cbis

\section{A B $\mathbf{S}$ T $\mathbf{R}$ A $\mathbf{C}$ T}

The Office of Religious Affairs or abbreviated as KUA has the functions of implementing marriage registration, referring, managing and fostering mosques, zakat, endowments, other social services and developing sakinah families, but what is very common in the KUA community is only a place to register and hold marriages. In $K U A$, the Koto subdistrict for the process of registering the bride and groom (catin) is still done by recording the ledger so that there is no guarantee the data will be stored and neatly organized. Then this research purpose of registering and submitting catin files which will be conducted online. So that the process of registering and submitting catin files will be stored in the database and safeguarding the data will be safer. Data collection techniques from this study were directly involved in the field with direct observation of the catin registration process, direct interviews and literature studies by using the System Development Life Cycle method. With this application, it is expected to be able to assist KUA officers and catin in the registration process so that the best service in the KUA office of Koto Tangah sub-district is created.

dalam pendaftaran pernikahan masih tulis tangan yang dicatat dalam buku besar, dengan demikian pengurus membutuhkan banyak buku dalam pencatatan pernikahan. Dimana Setiap minggunya pendaftaran pernikahan mencapai lebih dari 45 pasang catin yang akan melakukan pendaftaran, sehingga menyulitkan bagian pelayanan melanyani catin atau calon pengantin 
dengan maksimal. Setiap melayani catin petugas juga harus mengumpulkan berkas syarat nikah catin yang ditumpuk di dalam box file, sehingga tidak adanya jaminan bahwa data-data catin tersebut akan tersimpan dengan aman. Bahkan untuk mencari ulang data catin tersebut selalu membutuhkan waktu yang lama karena penyimpanannya masih bersifat arsip. Karena itulah perlu diciptakan sebuah aplikasi yang mampu mengolah data secara efektif. Aplikasi merupakan suatu program yang siap untuk digunakan yang dibuat untuk melaksanakan suatu fungsi bagi pengguna jasa aplikasi serta penggunaan aplikasi lain yang dapat digunakan oleh suatu sasaran yang akan dituju [1]. Salah satu untuk mengembangkan sebuah apliksi dengan menggunakan pemodelan Unified Modeling Languange (UML). UML merupakan sistem yang standar dalam industri untuk visualisasi, merancang dan mendokumentasikan sistem informasi [2]. Konsep perancangan menggunakan metode object oriented dengan menggunakan UML, yang terdiri dari: Use Case Diagram, Sequence Diagram dan Class Diagram

Sebelum penelitian ini dilakukan ada baiknya dibandingkan dengan penelitian yang dilakukan oleh peneliti sebelumnya. Givo Almuttaqin menggunakan metode waterfall hasil dari penelitian ini memudahkan proses pendaftaran pernikahan di KUA Kecamatan Mandau Duri pendaftaran catin secara online [3]. Jimsan menggunakan metode modified waterfall hasil dari penelitiannya dapat membantu proses pengelolaan data di KUA lebih cepat dan memudahkan pegawai KUA melaksanakan pelayanan [4]. Sedangkan Rizky Leonita Hapsari membuat Sistem Informasi Manajemen Nikah (SIMKAH) komputer yang berguna untuk mengumpulkan, mengolah dan Sistem Informasi Wakaf (SIWAK) aplikasi yang dikhususkan untuk benda - benda wakaf yang ada di Indonesia, serta menyimpan data dari seluruh KUA di Indonesia yang terkumpul secara online [5]. Penelitian yang dilakukan oleh Miftahul Ilmi dkk membantu dalam menghimpun data, pendaftaran dan pendataan pernikahan [6]. Berdasarkan 4 penelitian yang dilakukan oleh peneliti diatas pada umumnya hanya membahas tentang pendaftaran nikah secara online, dan tidak ada membahas tentang penyerahan berkas syarat nikah secara online. Maka dari itu kami melakukan penelitian tentang aplikasi pendaftaran dan penyerahan syarat nikah secara online. Yang nantinya aplikasi ini akan mempermudah kinerja dari petugas KUA dalam pendaftaran pernikahan dan pengumpulan berkas syarat nikah, karena aplikasi ini akan menerima berkas tersebut secara online. Sehingga petugas tidak perlu lagi mengarsipkan berkas syarat nikah. Aplikasi ini nantinya akan mempermudah petugas KUA dalam pembuatan laporan pencatatan pernikahan.

\section{KAJIAN LITERATUR}

\section{APLIKASI}

Aplikasi Secara istilah pengertian aplikasi adalah suatu program yang siap untuk digunakan yang dibuat untuk melaksanankan suatu fungsi bagi pengguna jasa aplikasi serta penggunaan aplikasi lain yang dapat digunakan oleh suatu sasaran yang akan dituju. Menurut kamus computer eksekutif, aplikasi mempunyai arti yaitu pemecahan masalah yang menggunakan salah satu tehnik pemrosesan data aplikasi yang biasanya berpacu pada sebuah komputansi yang diinginkan atau diharapkan maupun pemrosesan data yang di harapkan. Pengertian aplikasi menurut Kamus Besar Bahasa Indonesia, "Aplikasi adalah penerapan dari rancang sistem untuk mengolah data yang menggunakan aturan atau ketentuan bahasa pemrograman tertentu [1].

UML (Unified Modeling Language) 
UML (Unified Modeling Language) adalah salah satu standar Bahasa yang banyak digunakan di dunia industri untuk mendefinisikan requirement, membuat analisis dan desain, serta menggambarkan arsitektur dalam pemrograman berorientasi objek [7].

UML (Unified Modeling Language) dibuat untuk memudahkan developer, sehingga menciptakan suatu bahasa pemodelan yang dapat digunakan baik oleh manusia maupun mesin. UML tidak hanya digunakan dalam pemodelan perangkat lunak, namun hampir dalam semua bidang yang membutuhkan pemodelan. UML bisa juga diartikan sebagai grafik atau gambar digunakan untuk membangun dari sebuah sistem dan mengembangkan perangkat lunak berbasis objek (Object Oriented Programming).

\section{Pemograman Web}

Berdasarkan pemrosesan, pemrograman web dapat dibagi menjadi dua, yaitu 1) pemrosesan di sisi server dan 2) pemrosesan di sisi klien. Pemrosesan di sisi server berarti bahwa kode yang menyusun aplikasi web diproses di sisi server, sedangkan pemrosesan di sisi klien berarti bahwa kode yang menyusun aplikasi web diproses di sisi klien oleh browser [8].

Web merupakan teknik pemograman untuk menciptakan web pages. Diantara bahasa pemrograman yang dipakai untuk membangun aplikasi berbasis web adalah HTML, Javascript, PHP dan CSS.

\section{METODOLOGI}

\section{Metode Pengembangan Sistem}

Metode pengembangan perangkat lunak yang digunaka dalam dalam pembuatan sistem adalah System Development Life Cycle (SDLC) dengan model waterfall adapun penjelasan dari metode tersebut terdapat pada Gambar 1.

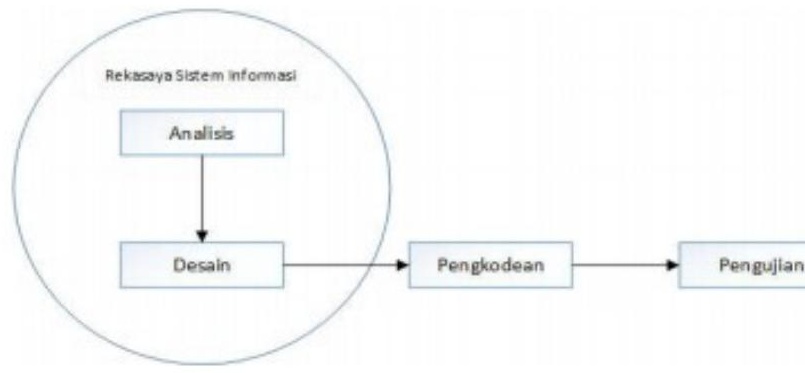

Gambar 1. Kerangka Kerja Penyelesaian Pengembangan Sistem

\section{a. Analisis Data}

Data fisik berkaitan data analisa komunikasi visual interaktif yang berkaitan spesifikasi aplikasi hardware dan software. Data primer diperoleh dari pengumpulan data menggunakan angket. Pada tahap ini akan dilakukan analisa terhadap data-data yang sudah dikumpulkan sebelumnya. Berdasarkan literaturliteratur yang ada, data yang didapat dari hasil wawancara dan studi lapangan maka didapatkan permasalahan yang sedang dihadapi oleh KUA koto tangah.

\section{b. Analisis Sistem}

Analisis sistem informasi difokuskan kepada masalah dan kebutuhan bisnis, tidak tergantung pada teknologi apapun yang akan digunakaan untuk mengimplementasikan solusi masalah yang dihadapi [10]. Analisis kebutuhan dilihat dari apa yang dibutuhkan oleh seorang user dan membuatkan dokumen kebutuhan seorang user.

\section{c. Desain Sistem}

Pada tahap ini akan dilakukan perancangan sistem dengan menggunakan model UML, ada 4 macam diagram yang digunakan yaitu : use case diagram, activity diagram, class diagram dan sequence diagram.

\section{d. Pengkodean Sistem}

Tahap ini dari penelitian yang dilakukan adalah melakukan pengkodean atau implementasi terhadap sistem yang dirancang. Sistem ini akan diimplementasikan pada KUA koto tangah kota Padang. 


\section{e. Pengujian Sistem}

Pada tahap ini dilakukan pengkajian kembali kelayakan dari sistem yang telah dirancang, apakah sistem tersebut sudah sesuai atau masih perlu dilakukan peninjauan kembali atau penyempurnaan.

\section{PEMBAHASAN}

\subsection{Perancangan Sistem}

Sebelum mencapai implementasi maka dibuat terlebih dahulu rancangan sistem menggunakan tools pada UML (Unified Modelling Language). Menurut munawar dalam yang terdiri dari use case diagram, sequence diagram dan class diagram seperti Gambar 1 sampai 5 dibawah ini.

\section{a. Use case Diagram}

Use case dideskripsikan secara tekstual dalam bentuk use case scenario untuk menjelaskan interaksi yang terjadi antara aktor dengan sistem [11]. Use case diagram dapat digunakan selama proses analisis untuk menangkap requirements atau permintaan terhadap aplikasi pendaftaran dan penyerahan berkas persyaratan nikah. Untuk memahami bagaimana sistem tersebut harus bekerja, yang dapat dilihat pada Gambar 2 yang menggambarkan struktur kerja dari pada admin. Gambar 3 menjelaskan kegiatan apa saja yang akan dilakukan oleh catin.

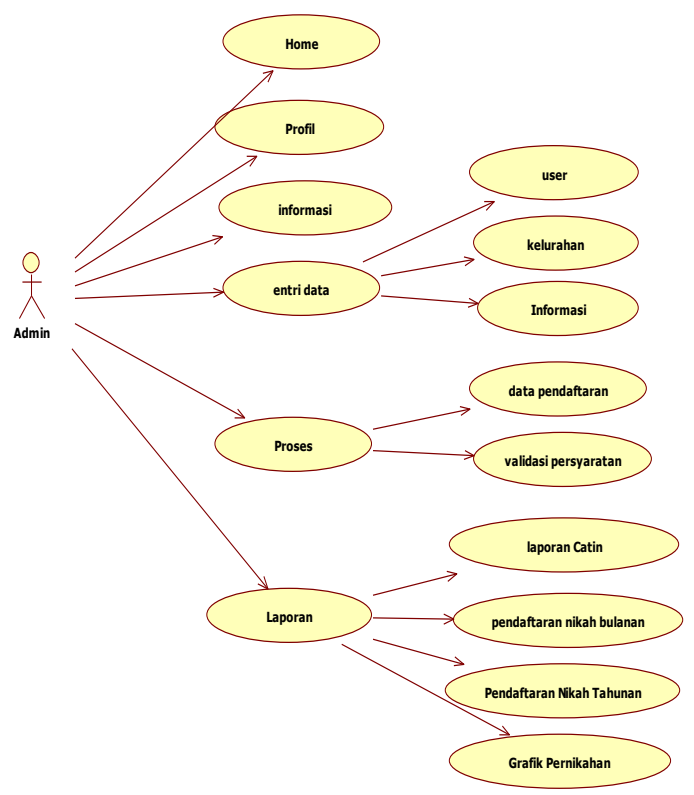

Gambar 2. Use Case Diagram Admin

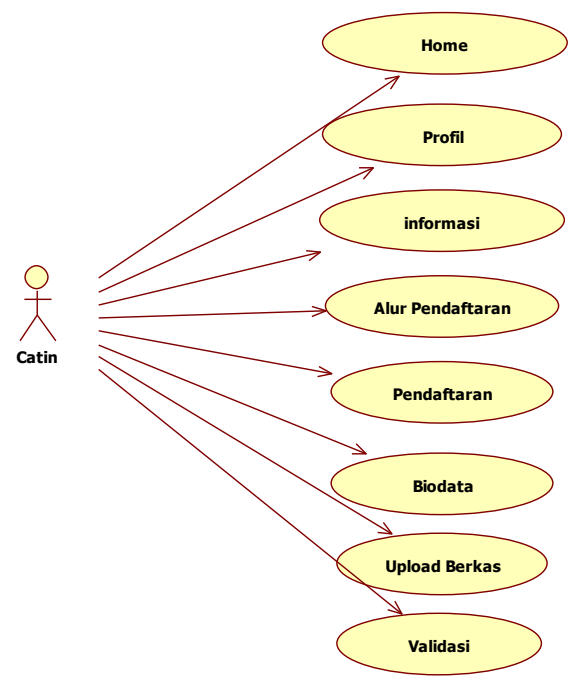

Gambar 3. Use Case Diagram Catin

\section{b. Activity Diagram}

Activity diagram menggambarkan proses - proses yang terjadi mulai aaktifitas dimulai sampai aktivitas berhenti. Activity diagram juga dapat menggambarkan proses paralel yang mungkin terjadi pada beberapa eksekusi [10]. Adapun activity diagram sistem informasi pendaftaran dan penyerahan berkas persyaratan nikah KUA Kecamatan Koto Tangah dapat dilihat pada Gambar 4. 


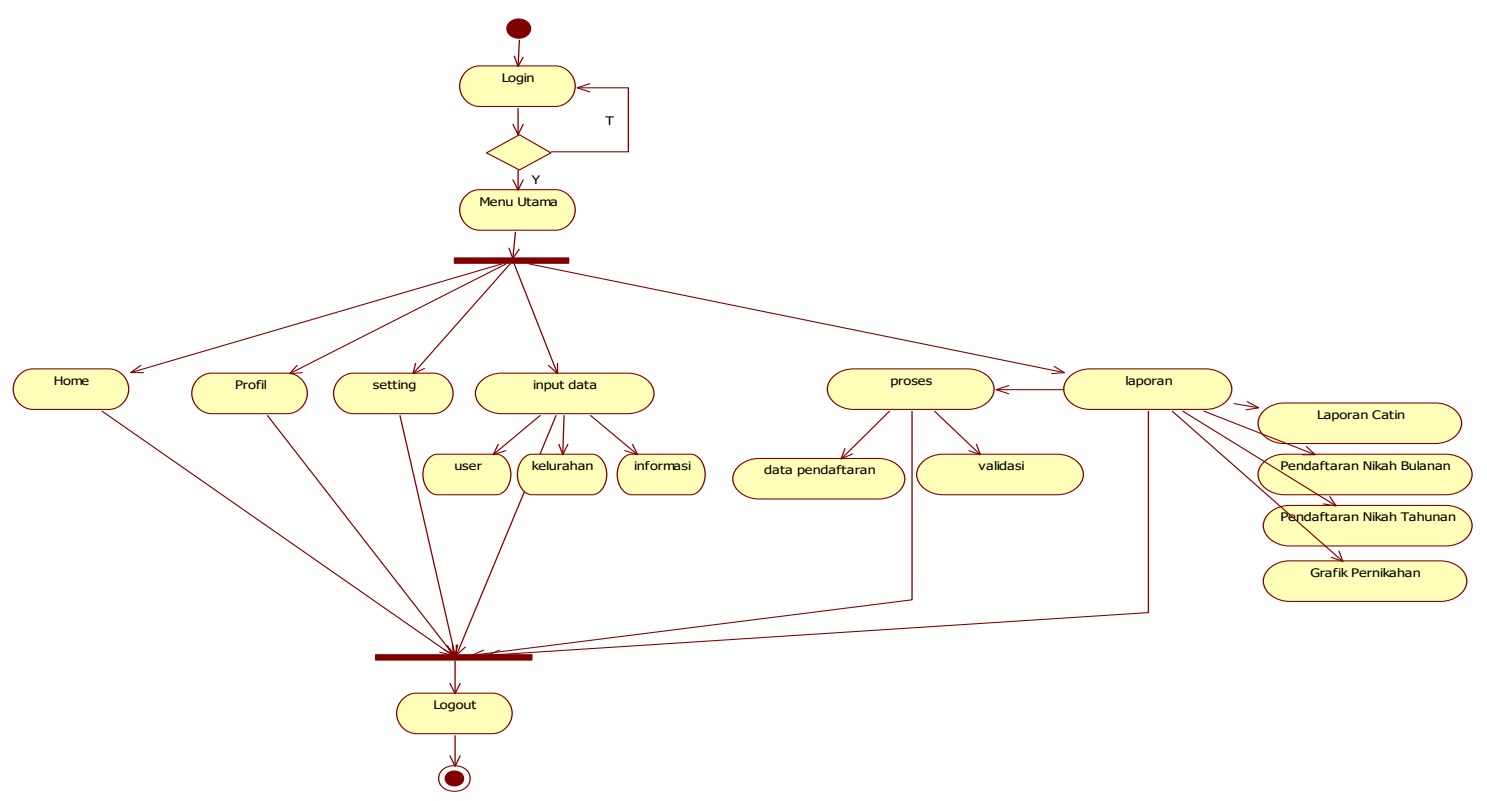

\section{c. Sequence Diagram}

Gambar 4. Activity Diagram

Berdasarkan analisis dari Activity Diagram, maka dibuatlah sequence diagram untuk perancangan alur pemrograman di dalam class nantinya. Pada penerapannya, konsistensi desain sequence diagram yang diimplementasi sering menjadi masalah dalam pembangunan perangkat

lunak [12]. Sequence diagram digunakan untuk menggambarkan skenario atau rangkaian langkahlangkah yang dilakukan sebagai respons dari sebuah event untuk menghasilkan output tertentu. Diawali dari apa yang men-trigger aktivitas tersebut, proses dan perubahan apa saja yang terjadi secara internal dan output apa yang dihasilkan dapat dilihat pada Gambar 5.

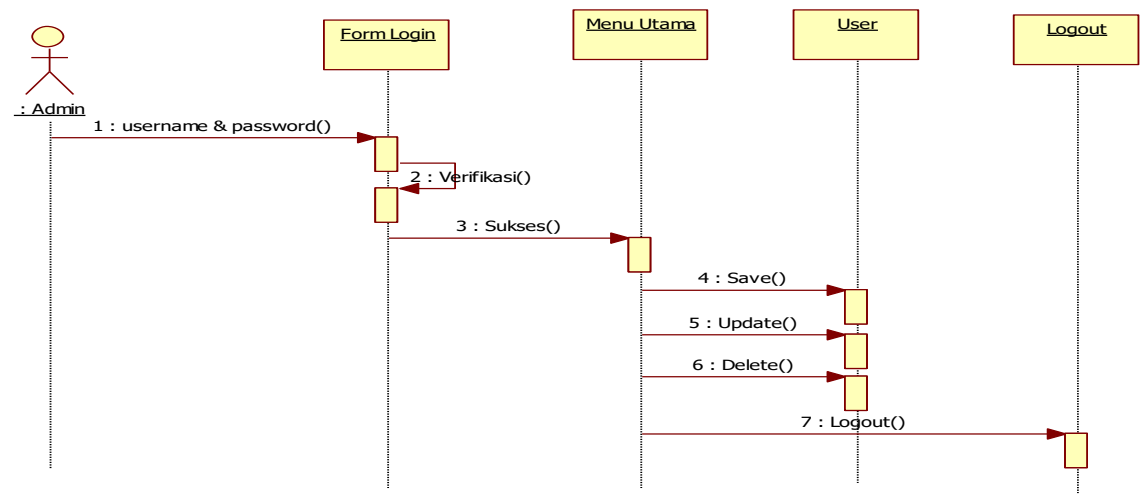

Gambar 5. Sequence Diagram

\section{d. Class Diagram}

Class diagram adalah sebuah spesifikasi yang jika diinstansiasi akan menghasilkan sebuah objek dan merupakan inti dari pengembangan dan desain berorientasi objek pada sistem informasi 
pendaftaran dan penyerahan berkas persyaratan nikah KUA Kecamatan Koto Tangah. Adapun class diagram Kantor KUA Kecamatan Koto Tangah dapat digambarkan seperti Gambar 6.

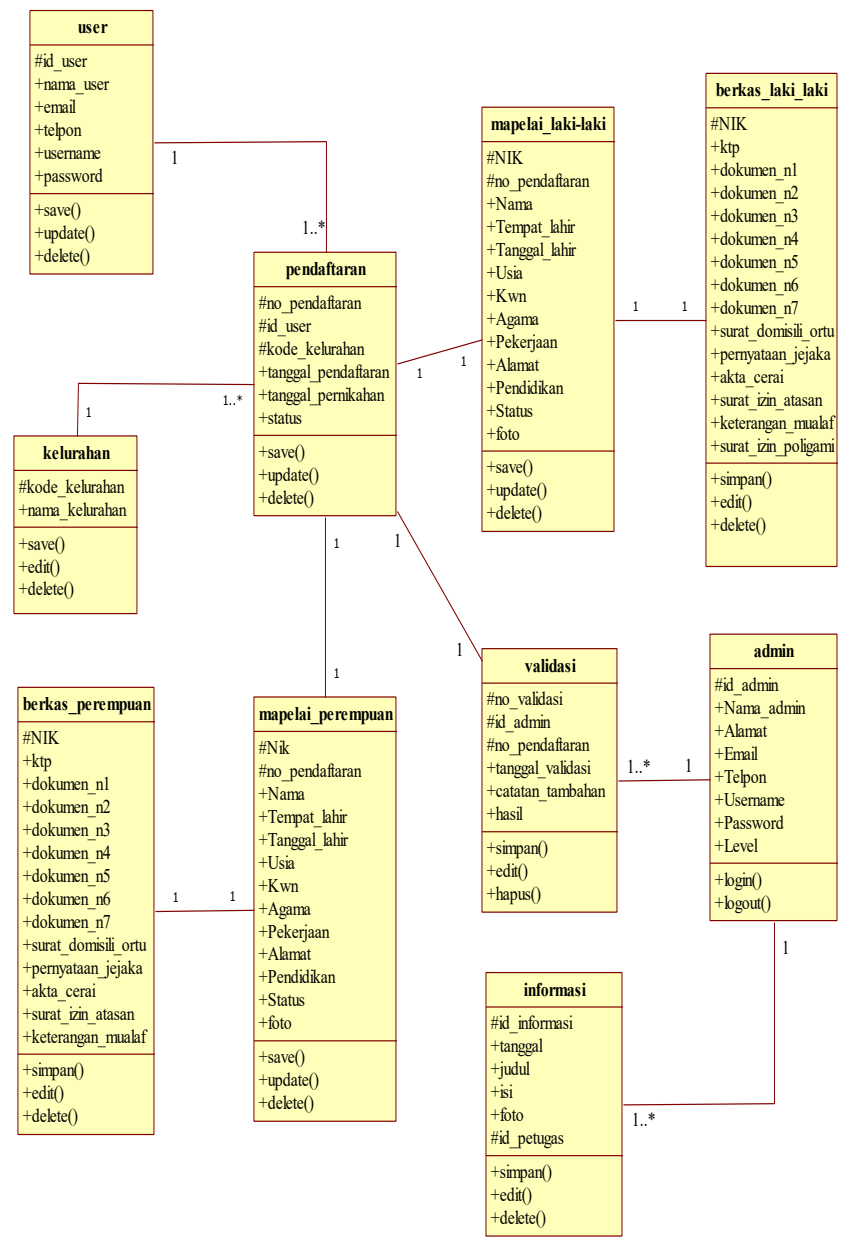

Gambar 6. Class Diagram

\subsection{Implementasi Sistem}

Tahap implementasi pada sebuah sistem informasi merupakan tahap dimana sistem yang telah dirancang pada tahap sebelumnya diterapkan atau dioperasikan.

\subsubsection{Tampilan Home}

Home merupakan tampilan pertama dari aplikasi pendaftaran pernikahan yang diakses lewat web. Tampilan home dapat dilihat pada Gambar 7.

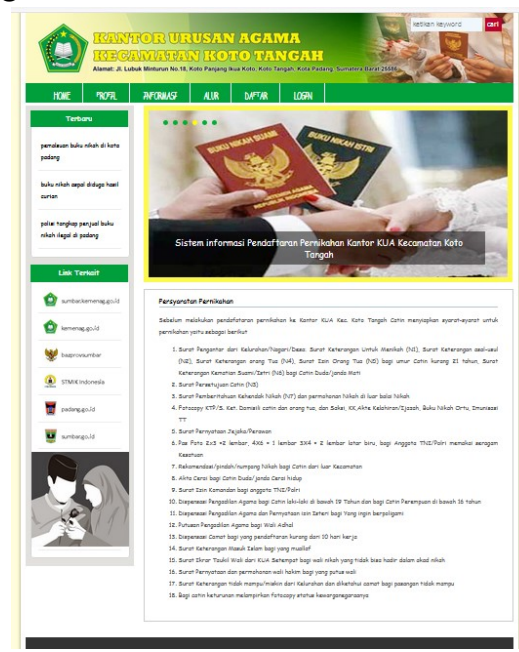




\subsubsection{Tampilan Input}

a. Tampilan Input Pendaftaran Akun Catin

Sebelum catin masuk kedalam sistem pendaftaran atau aplikasi maka catin harus memiliki akun terlebih dahulu dengan cara mendaftar secara langsung melalui aplikasi, akun tersebut dapat digunakan untuk $\log$ in kedalam aplikasi adapun tampilan daftar dapat dilihat pada Gambar 8.

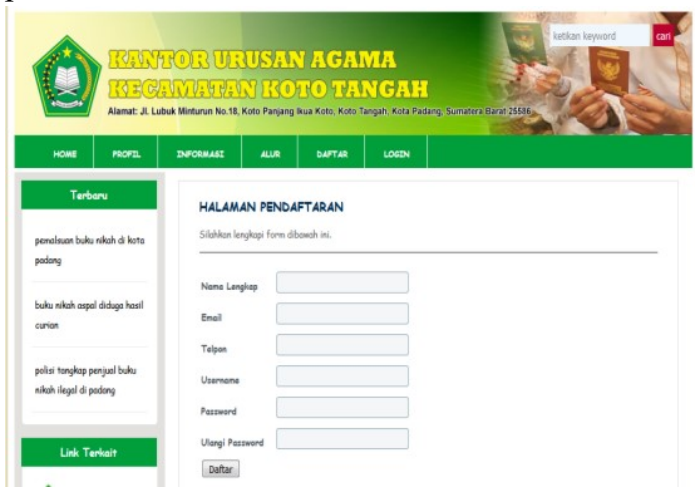

Gambar 8. Tampilan Form Daftar

\section{b. Tampilan Input Log in}

Dalam menu log in harus memasukan user name dan password yang telah dibuat, untuk log in terdiri dari tiga hak akses yaitu catin, admin, dan pimpinan semua bisa $\log$ in sesuai hak akses yang dimiliki dan bisa dilihat pada Gambar 9 .

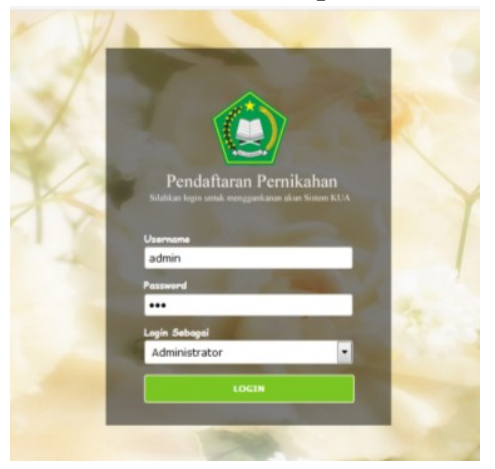

Gambar 9. Tampilan Log In

\section{c. Tampilan Input Biodata Catin}

Setelah mendaftar dan memiliki akun, catin $\log$ in dan mengisi biodata catin laki - laki dan catin perempuan. Saat mengisi biodata semua harus diisi dengan benar dan teliti supaya tidak salah. Tampilan biodata dapat dilihat pada Gambar 10.

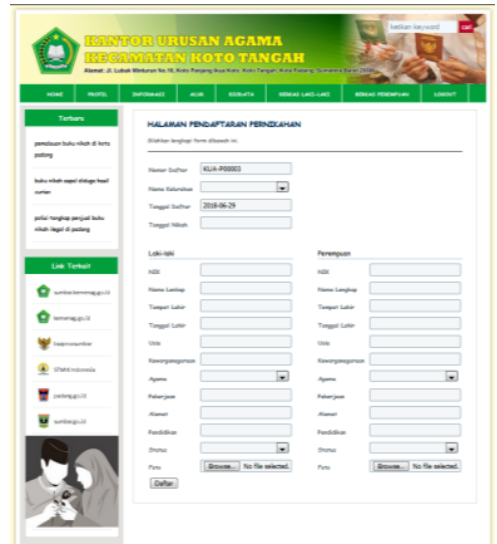

Gambar 10. Tampilan Form Biodata

d. Tampilan Input Berkas Catin Laki - Laki

Pada tampilan ini banyak berkas yang perlu di upload sesuaikan dengan persyaratan yang harus catin penuhi dan jangan lupa memasukkan tanggal nikah serta foto catin, form upload berkas catin laki - laki bisa kita lihat pada Gambar 11.

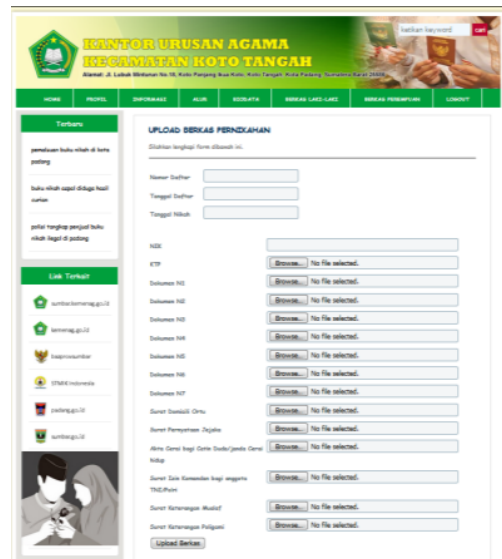

Gambar 11. Tampilan Form Upload

Berkas Catin Laki - Laki

e. Tampilan Input Berkas Perempuan

Tampilan form berkas perempuan sama dengan tampilan form upload berkas laki - laki setelah diisi dengan benar dan sudah diupload catin bisa memilih menu log out untuk keluar atau kembali ke home apabila sudah selesai. Lebih jelasnya bisa dilihat pada Gambar 12 . 


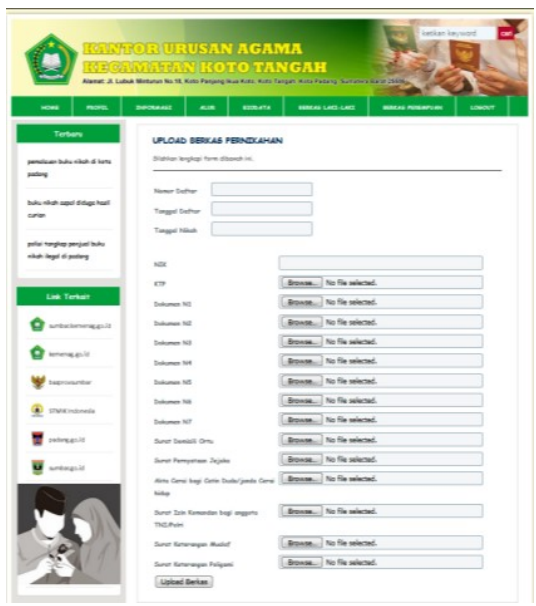

Gambar 12. Tampilan Form Upload

Berkas Catin Perempuan

f. Tampilan Input Validasi Pendaftaran

Setelah catin menylesaikan pendaftaran setelah itu divalidasi oleh admin seperti pada Gambar 13

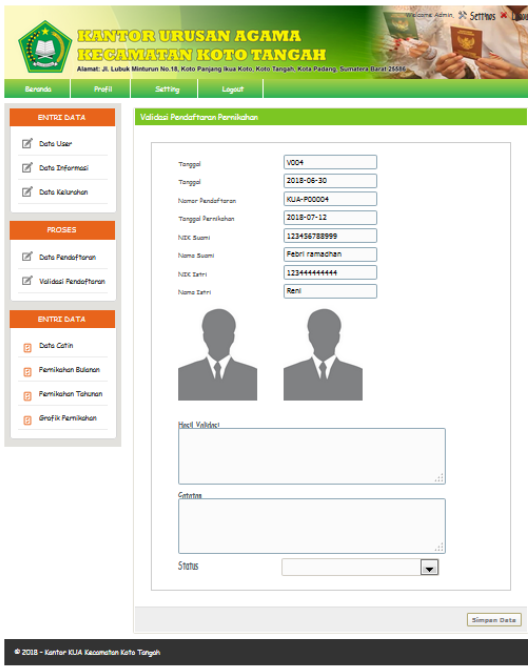

Gambar 13. Form Input Validasi

\subsubsection{Tampilan Output}

a. Tampilan Output Laporan Data Catin

Untuk laporan data catin bisa dilihat diaplikasi berdasarkan bulan sehingga memudahkan baik penghulu ataupun pimpinan melihat catin yang akan melangsungkan pernikahan, seperti pada Gambar 14.

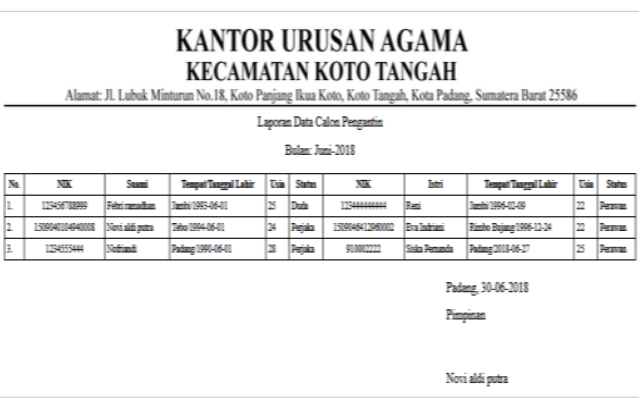

Gambar 14. Laporan Data Catin

b. Tampilan Output Laporan Menggunakan Grafikan

Pada tampilan grafik ini menampilkan laporan dalam bentuk grafik atau Gambar, bisa dilihat berdasarkan tingggi rendahnya angka pernikahan dan disesuaikan dengan pernikahan yang ada perbulan seperti pada Gambar 15 .

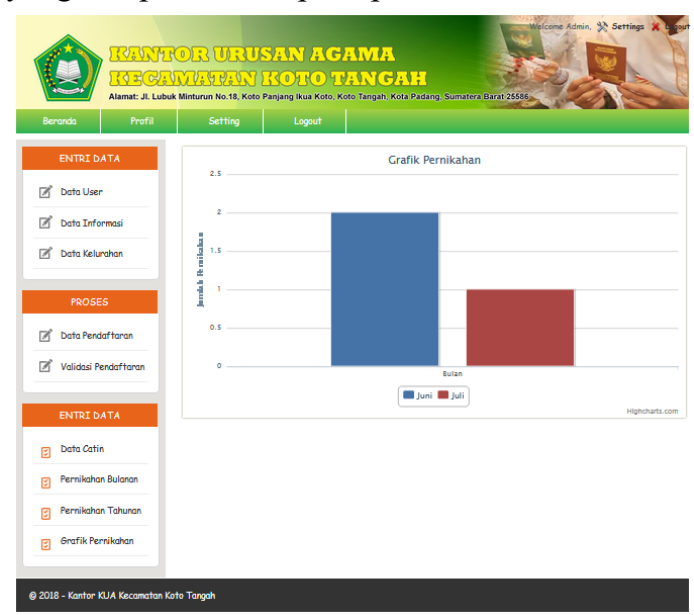

Gambar 15. Laporan Pernikahan Dengan Grafik

\section{KESIMPULAN}

Berdasarkan aplikasi pendaftaran dan penyerahan syarat nikah yang telah dibuat maka diperoleh kesimpulan sebagai berikut :

a. Dengan adanya aplikasi ini catin yang ada di Kec. Koto Tangah tidak perlu lagi datang ke KUA koto tangah untuk melakukan pendaftaran pernikahan.

b. Adanya aplikasi ini sangat mempermudah petugas KUA dalam meningkatkan pelayanan terhadap masyarakat. 


\section{UCAPAN TERIMA KASIH}

Ucapan terima kasih kami ucapkan kepada STMIK Indonesia Padang atas pendanaan penelitian hibah dosen STMIK Indonesia Padang dengan no kontrak : 014/K.A/LPPM/STMIK$\mathrm{I} / 2018$.

\section{DAFTAR PUSTAKA}

[1] J. Ilmiah, I. Komputa, E. Volume, A. Issn, and A. Juansyah, "PEMBANGUNAN APLIKASI CHILD TRACKER BERBASIS ASSISTED GLOBAL POSITIONING SYSTEM ( A-GPS ) DENGAN PLATFORM ANDROID Jurnal Ilmiah Komputer dan Informatika ( KOMPUTA ), 2015.

[2] F. Liantoni and A. Yusincha, "Pemodelan UML Pada Sistem Pengajuan Dana Anggaran Untuk Peningkatan Produktivitas Perusahaaan," Digit. Zo. J. Teknol. Inf. dan Komun., vol. 9, no. 2, pp. 94-105, 2018, doi: 10.31849/digitalzone.v9i2.1763.

[3] G. Almattaqin, "SISTEM INFORMASI PENDAFTARAN PERNIKAHAN BERBASIS ONLINE MENGGUNAKAN METODE WATERFALL ( STUDY KASUS : KANTOR URUSAN AGAMA KECAMATAN," vol. 2, no. 2, pp. 5255, 2016.

[4] M. Qomaruddin, "Sistem Informasi Manajemen Data Pernikaha Pada Kantor Urusan Agama ( KUA ) Bonegunu," vol. 2, no. 1, pp. 57-67, 2017.

[5] R. . Hapsari, "SISTEM INFORMASI MANAJEMEN BERBASIS TEKNOLOGI
INFORMASI
MANAGEMENT

INFORMATION

SYSTEMS BASED

ON

INFORMATION," pp. 1-12.

[6] M. Ilmi et al., "PERANCANGAN SISTEM INFORMASI PERNIKAHAN DAN STATUS PERNIKAHAN KANTOR URUSAN AGAMA KECAMATAN CANDUANG AGAM BERBASIS WEB DENGAN FRAMEWORK CODEIGNITER," vol. 4, no. 1, 2016.

[7] A. . Rosa and M. Shalahuddin, Rekayasa Perangkat Lunak Terstruktur dan Berorientasi Objek, 4th ed. Bandung: Informatika Bandung, 2016.

[8] A. Kadir, Teknologi Informasi. (Ed II). Yogyakarta: Andii, 2013.

[9] A. Kadir, Javascript dan jQuery, Rahasia Untuk Menguasai Pembuatan Aplikasi Web yang Interaktif dan Dinamis. Yogyakarta: Penerbit Andi, 2013.

[10] R. Turaina and N. E. Putri, "Expert System For Determining Lecturer Performance Based On Tridharma With Fuzzy Metods," vol. 2, pp. 20-30, 2016.

[11] T. A. Kurniawan, "PEMODELAN USE CASE ( UML ): EVALUASI TERHADAP BEBERAPA KESALAHAN DALAM PRAKTIK USE CASE ( UML ) MODELING : EVALUATION ON SOME PITFALLS IN PRACTICES," vol. 5, no. 1, pp. 7786, 2018, doi: 10.25126/jtiik.201851610.

[12] I. K. Raharjana and A. Justitia, "ENGINEERING APLIKASI BASIS DATA PADA SMARTPHONE," pp. 133-142.2015 